\title{
Sample size requirements for pilot randomised controlled trials with continuous outcomes: a simulation study
}

\author{
Marion Teare, Alexandra Hayman, Munya Dimairo*, Neil Shephard, Amy Whitehead, Stephen Walters \\ From 2nd Clinical Trials Methodology Conference: Methodology Matters \\ Edinburgh, UK. 18-19 November 2013
}

\begin{abstract}
Aims
There is lack of consensus over what sample size should be used for external pilot trials to inform the design of definitive parallel group superiority randomised controlled trial (RCT). The aim of this research was to investigate the sample size required to precisely estimate the key parameter associated with a continuous outcome, the standard deviation (SD).
\end{abstract}

\section{Methods}

We use a simulation approach to examine the sampling distribution of the SD for a Normally distributed outcome. We assessed the precision of the estimates by calculating the relative gain in precision through the width of the $95 \%$ confidence interval (CI) and the percentage gain in precision per increase in sample size of 5 in each group.

\section{Results}

The bias in the pooled SD estimate is negligible once the total pilot sample is 60 or above and the relative gain in precision (for each ten subjects added to the pilot) drops to below $10 \%$ once the total sample size is 70 . When planning the full RCT for a continuous outcome, estimates generated by pilot samples of 70 will have the required power with close to $50 \%$ confidence when the true standardised effect size is above 0.2 . Adjusting the required sample sizes for the full RCT to deliver the required power with $80 \%$ confidence can result in excessively large full planned RCTs.

University of Sheffield, Sheffield, UK

C 2013 Teare et al; licensee BioMed Central Ltd. This is an Open Access article distributed under the terms of the Creative Commons Attribution License (http://creativecommons.org/licenses/by/2.0), which permits unrestricted use, distribution, and reproduction in any medium, provided the original work is properly cited.

\section{Conclusions}

We recommend that an external pilot study needs at least a total of 70 measured subjects (35 per group) to estimate the pooled SD for a continuous outcome.

Published: 29 November 2013

doi:10.1186/1745-6215-14-S1-P46

Cite this article as: Teare et al.: Sample size requirements for pilot randomised controlled trials with continuous outcomes: a simulation study. Trials 2013 14(Suppl 1):P46.
Submit your next manuscript to BioMed Central and take full advantage of:

- Convenient online submission

- Thorough peer review

- No space constraints or color figure charges

- Immediate publication on acceptance

- Inclusion in PubMed, CAS, Scopus and Google Scholar

- Research which is freely available for redistribution 